\title{
O RIO: LUGAR SAGRADO DA LITERATURA AMERÍNDIA
}

EDSON K. DORNELES ${ }^{1}$

UFSCAR

RESUMO: $O$ rio nos convida a ver de mil formas: lente e embaçamento dos olhos, é uma pedagogia perspectivista. Em suas perenes mas inconstantes águas, nos conduz a nômades segredos revelados sobre a natureza humana. Perspectivismo e inconstância são duas vertentes para compreender a literatura ameríndia, tal como a navegamos neste ensaio. Eduardo Viveiro de Castro. Escritores indígenas desse Brasil. Milton Hatoum. Guimarães Rosa. Almas ameríndias que ora mergulham ora flutuam nessas águas revoltosas.

PALAVRAS-CHAVE: Rio; literatura; semiótica.

ABSTRACT: The river invites us to see in a thousand ways: blurring and lens of the eye, it's perspectivist pedagogy. In its perennial but fickle waters leads us to nomadic revealed secrets about human nature. Perspectivism and instability are two adoptable aspects to understand Amerindian literature such as sailed in this essay. Eduardo Viveiros de Castro. Indigenous authors of Brazil. Milton Hatoum. Guimarães Rosa. Amerindian souls which sometimes are diving and sometimes are floating in these rebel waters.

KEYWORDS: River; indigenous literature; french semiotics.

Mirar el río hecho de tiempo y agua

$Y$ recordar que el tiempo es otro río,

Saber que nos perdemos como el río

$Y$ que los rostros pasan como el agua.

(...)También es como el río interminable

Que pasa y queda y es cristal de un mismo

Heráclito inconstante, que es el mismo

$Y$ es otro, como el río interminable.

Jorge L. Borges (2012, n/p).

\footnotetext{
${ }^{1}$ Mestrando no programa de pós-graduação em Estudos Literários da Universidade Federal de São Carlos (2012-2013), possui licenciatura em Português e Espanhol por esta universidade, e especialização em Teologia (2005) pelo Seminário Presbiteriano do Norte, Recife, PE. Escreve contos e poesias. É descendente de terceiro grau do povo Krenak de Minas Gerais. E-mail: edsonkrenak@gmail.com.
}

Espaço Ameríndio, Porto Alegre, v. 6, n. 2, p. 76-96, jul./dez. 2012. 


\section{Nascente}

iRio Grande de Loíza!... Alárgate en mi espíritu y deja que mi alma se- pierda en- tus riachuelos para buscar la fuente que te robó de niño y en un ímpetu loco te devolvió al sendero. Julia de Burgos (1998, p. 85) ${ }^{2}$.

Neste artigo com jeito de ensaio propomos uma análise de bases fenomenológica e antropológica de um espaço narrativo: o rio. Em qualquer dicionário ou tratado geográfico encontraremos a definição de rio como um curso natural de água. O rio representa relação mais antiga da humanidade com a água, seja de ordem econômica ou espiritual. A água possui um poder simbólico profundo e, desde os tempos imemoriais, o homem se serve dela para expressar suas necessidades existenciais, físicas e míticas.

Num plano simples de observação fenomenal, o rio é/se apresenta como uma realidade semilivre da água - quase totalmente rodeado pelas margens e pelo leito de terra. Em seu estudo sobre a água, $A$ água e os Sonhos, Gaston Bachelard aposta na profundidade, na cor e na mobilidade da água ressaltando duas características opostas: água viva, de superfície, e água morta, profunda - "suporte material da morte" (BACHELARD, 1997, p. 71). Não consideramos esses critérios decisivos, pois, como ressalta o teólogo Marc Girard, a mesma água pode reunir quatro grandes propriedades ao mesmo tempo: fazer viver, dissolver, apagar o fogo e fazer morrer. (GIRARD, 1997, p. 188). E, ao analisar sua valência, dentro de uma perspectiva tensiva, a água pode ser cativante e liberante, reunindo uma gradiência de vários matizes simbólicos. Quando a água é usada, por exemplo, para purificar (rituais religiosos ou culinários, entre outros), as ações podem ser de ablução,

\footnotetext{
${ }^{2}$ Todas as epígrafes são da poetisa porto-riquenha Julia de Burgos, poema Río Grande de Loíza, da coletânea Song of the Simple Truth: The Complete Poems of Julia de Burgos, Obra Completa Poetica. Publishers Weekly, February 24, 1998, p. 85, gentilmente cedida pela pesquisadora Miraida G. Villegas Zapa de Porto Rico.
}

Espaço Ameríndio, Porto Alegre, v. 6, n. 2, p. 76-96, jul./dez. 2012. 
aspersão e/ou imersão, a mesma ação, de purificar, pode ser feita com intensidade e extensidade diversas.

Outro aspecto de sua valência simbólica dentro da antropologia é ressaltado ainda por Girard: "a água remete ao mistério de três aspirações profundamente ancoradas no homem: sua aspiração a sobreviver, a livrar-se de suas sujeiras e a conhecer os segredos do real" (GIRARD, 1997, p. 198). Quando mata a sede, quando os livra das impurezas causadoras de doenças e males e quando, num contexto poético e religioso, representa a sabedoria ${ }^{3}$, o oculto, o mistério.

Cada rio tem sua história, seguindo o curso de suas águas, que pode ser resumida em três fases: fonte, curso e deságua; este último pode formar um charco, se perder num outro rio ou lago, ou simplesmente desaparecer no mar. Ao observarmos essas fases, percebemos que a água tende a voltar à sua origem. Ampliando nossa perspectiva fenomenológica, as águas possuem uma história tensiva que força o jorro para sua manifestação, escorre numa gradiência (onde velocidade, lentidão, largueza e estreiteza, limite e profundidade constituem seus valores) de antiaparecimento, aparecimento e desaparecimento. É uma dialética de doar a vida, nutri-la e desaparecêla novamente.

Ler o rio é ler o que está presente (na superfície) e o que está ausente (além, submerso); é perceber no semiaprisionamento das águas, atributo do rio, a ambivalência, ou melhor, a polivalência de continente, conteúdo, gerador de vida e de morte; nela o masculino e o feminino convivem na bissexualidade; a vida e a morte se distraem.

As águas estão presentes em toda literatura mundial e quando observamos as literaturas ameríndias, assim como as indígenas de cada continente 4 . A América possui as suas veias compostas por rios, ela é definida pelos seus rios: região do Paraná, Del Plata, Orinoco, Xingu, Rio Amazonas. São Francisco, Rio Doce e mais ao norte El Gran Río de Loíza

\footnotetext{
${ }^{3}$ Tanto Mircea Eliade (1979) como Bachelard (1997) mostram exemplos de religiões, filosofias e poetas que apresentaram as águas semilivres (rios e oceanos) como a casa da sabedoria. No livro bíblico de Ezequiel, as águas do rio que saem do trono são capazes de dar respostas oraculares às questões humanas: ao mergulhar nas águas, o profeta mergulha no mistério e o compreende.

${ }^{4}$ Um belo exemplo está na novela The Whale Rider, de Witi Ihimaera (1987), onde toda a trama se passa às margens do mar, a relação dos indígenas com as baleias na luta pela preservação das tradições.
}

Espaço Ameríndio, Porto Alegre, v. 6, n. 2, p. 76-96, jul./dez. 2012. 
no Caribe, entre tantas extensões de águas cantadas e romanceadas por xamãs, poetas e escritores das Américas através dos séculos.

Como no poema de Borges (2012), trazido na epígrafe, prevenimos que este texto há de ser um rio interminável, mas na medida em que se transformar em outros rios, outras águas, deixará de cantar aqui seu canto. Mas, antes disso, mirar el rio é necessário para percebermos seu tempo, sua face, inspirados pelo mapa poético da poetiza caribeña Valerie Bloom (2012) no poema River 5 e de Júlia de Burgos (1998), outra caribeña que alimentará este ensaio com a afluência das epígrafes. Vamos mostrar o curso do rio na literatura ameríndia através de três obras: A coletânea Te mandei um passarinho (XACRIABÁ et al, 2007), de vários autores indígenas brasileiros de várias etnias, publicada pelo Ministério da Educação; a novela Órfãos do Eldorado, romance do escritor amazonense Milton Hatoum (2008); e o conto Terceira Margem do Rio, de Guimarães Rosa (1969).

\title{
Um nômade, um andarilho de palavras
}

\begin{abstract}
iRío Grande de Loíza!... Azul. Moreno. Rojo.
Espejo azul, caído pedazo azul de cielo; desnuda carne blanca que se te vuelve negra cada vez que la noche se te mete en el lecho

roja franja de sangre, cuando bajo la lluvia a torrentes su barro te vomitan los cerros. Julia de Burgos (1998, p. 85).
\end{abstract}

\section{Guimarães Rosa disse que amava}

os grandes rios, pois são profundos como a alma do homem. Na superfície são muito vivazes e claros, mas nas profundezas são tranqüilos e escuros como os sofrimentos dos homens. Amo ainda mais uma coisa de nossos grandes rios: a eternidade. Sim, rio é uma

\footnotetext{
${ }^{5}$ The river: The river's a wanderer, a nomad, a tramp/ He doesn't choose any one place to set up his camp./ The river's a winder, through valley and hill./ He twists and he turns, he just cannot be still./ The river's a hoarder and he buries down deep/ Those little treasures that he wants to keep./ The river's a baby, he gurgles and hums/ And sounds like he's happily sucking his thumbs./ The river's a singer, as he dances along/ The countryside echoes the notes of his song./ The river's a monster, hungry and vexed/ He's gobbled up trees and he'll swallow you next (BLOOM, 2012).
}

Espaço Ameríndio, Porto Alegre, v. 6, n. 2, p. 76-96, jul./dez. 2012. 
EDSON K. DORNELES - O Rio: lugar sagrado da literatura ameríndia

palavra mágica para conjugar a eternidade (ROSA apud IMS, 2006, p. 24).

Quando observamos o conto Terceira Margem do Rio, o mais conhecido das Primeiras Estórias, percebemos o quanto o rio pode parar a vida na terra, na margem ou movê-la com suas palavras que calam o homem. Os contos de Primeiras Estórias nas palavras do seu autor:

\begin{abstract}
Pretendem ser um manual de metafísica e uma série de poemas modernos. Quase cada palavra, nele, assume pluralidade de direções e sentidos, tem uma dinâmica espiritual, filosófica, disfarçada. Tem de ser tomado de um ângulo poético, anti-racionalista e anti-realista (...). é um livro contra a lógica comum, e tudo nele parte disso. Só se apoia na lógica para transcendê-la, para destruí-la (ROSA apud IMS, 2006, p. 32).
\end{abstract}

As direções transcendentais que tomam o conto na vida de seus inominados personagens, que absorvem a aparente loucura do pai, esposo e protagonista, que se apaixona pelo rio e abre mão de viver em família, na terra, para ir em direção "rio abaixo, rio a fora, rio a dentro" (ROSA, 2006, p. 86). Seu filho, o narrador da história, parece não entender o pai; embora perseguisse, tentasse, se aproximasse do pai, talvez jamais pudesse se apoiar sobre o rio, adentrá-lo, seguir suas direções, pois buscava o pai, enquanto este buscava o rio, os caminhos do rio. Fracassou em substituir o pai, pois não abandonou a lógica comum da vida em família, queria ir e voltar, queria um caminho realista de solução dos problemas: "Sou homem de tristes palavras. De que era que eu tinha tanta culpa? Se o meu pai, sempre fazendo ausência: e o rio-rio-rio, o rio-pondo perpétuo" (ROSA, 2006, p. 83). Para transcender é preciso colocar o mundo entre parêntesis, não estar somente sobre o rio, mas dentro o rio, deixar que sua geografia metafísica seja despertada, provocada, conhecida e revolvida no fundo da alma.

Daniel Munduruku parece estar tratando disso ao afirmar que as histórias das coisas precisam ser despertadas - "Parecem um pouco com areia no fundo do rio: estão lá, bem tranquilas, e só deixam sua tranquilidade quando alguém as revolve. Aí elas se mostram" (MUNDURUKU apud XACRIABÁ et al, 2007, p. 27). 
Na coletânea de prosas e versos dos índios do Brasil Te Mandei um Passarinho (XACRIABÁ et al, 2007), publicação de vários escritores indígenas brasileiros, encontramos a mesma metafísica do rio, controlando a vida de dentro e de fora, aprisionando espaços, libertando seres, estabelecendo novas direções, como neste poema:

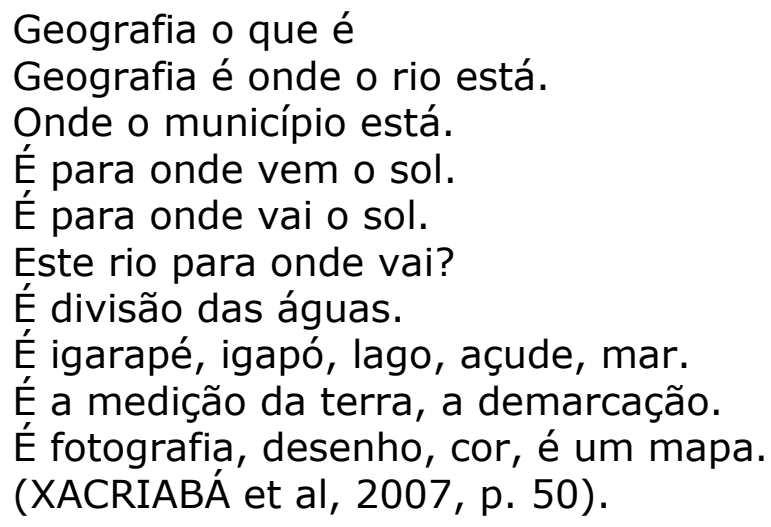

É o rio que recebe a geografia e dá a demarcação, palavras tão importantes para as comunidades indígenas, ribeirinhas, fazendeiros e políticos: todas as questões espirituais e econômicas desses atores passam por essa geografia de sentidos e direções tão diversas e ambivalentes. Se olhassem para o rio, quantos problemas não seriam resolvidos e deixariam de existir simplesmente porque para o rio não existe necessidade de demarcação, de novas direções: a geografia, o desenho, o mapa já estão aí mostrando o caminho do sol, da cidade. Sigam o rio! Parecem dizer os Professores Indígenas do Acre (XACRIABÁ et al, 2007, p. 50).

Arminto Cordovil ouve sua voz, a voz do rio, vai em busca de Dinaura, sua amada. Mas encontra somente silêncio dela, pois o rio fala, puxa, migra e, como um andarilho, mostra seus visitantes: homens cegos de ambição, crianças indígenas violentadas, a cidade contornando o rio, pessoas clamando sua ajuda. O rio é o mapa pelo qual navegam, se dirigem e se orientam, em busca de sentidos, as personagens de Órfãos do Eldorado, de Milton Hatoum (2008).

As andanças que o rio proporciona a Arminto fazem lembrar a origem mítica do povo Karajá:

Karajá - De onde vieram os Karajá? Do fundo do rio, onde viviam. Eram os Berahatxi Mahadu, o povo do 
EDSON K. DORNELES - O Rio: lugar sagrado da literatura ameríndia

fundo das águas. Um dia, descobriram a passagem para a superfície e boiaram no rio Araguaia. Lá, encontraram doenças e morte. Tentaram voltar, mas a passagem estava fechada (XACRIABÁ et al, 2007, p. 64).

Por que o rio? Talvez porque talvez ele seja mais próximo da alma humana do que possamos imaginar. Eduardo Viveiros de Castro nos faz pensar sobre o canibalismo entre alguns povos amazônicos como um "ponto extremo de um gradiente de sociabilidade, cujo outro polo seria a indiferença ou a incomunicabilidade" (VIVEIROS DE CASTRO, 2011 , p. 263), que, no caso dos Tupinambá, sua perda (do canibalismo) significaria a "perda de uma dimensão essencial, a autodeterminação pelo outro" (VIVEIROS DE CASTRO, 201 1, p. 263).

Córrego e corredeira são palavras que usamos para definir tipos de rio. Trazem também seu nomadismo e sua indecifrável possibilidade de uma só ocorrência; ele se repete de outras formas. Ele corre dos mesmos lugares para os lugares de sempre, mas os perdemos. Essa instabilidade instável do rio aponta para a volubilidade da alma humana, para os reveses da vida na terra, mas mais que isso clarifica a alma ameríndia em sua inconstância ontológica. O rio não abre mão de sua inconstância; ambivalente, consegue manter sua gradiência entre as margens, o leito e o céu. Mesmo inquieto.

\section{Um inquieto, um inconstante de alma}

$$
\begin{array}{r}
\text { Apéate un instante del lomo de la tierra, } \\
\text { y busca de mis ansias el íntimo secreto; } \\
\text { confúndete en el vuelo de mi ave fantasía, } \\
\text { y déjame una rosa de agua en mis ensueños. } \\
\text { Julia de Burgos (1998, p. 85). }
\end{array}
$$

Há um conceito fundamental a respeito do ameríndio. Às vezes tão relacionado com o rio que lhe é difícil separar. Inconstância. Conceito que representa um esforço original e analítico dentro dos estudos antropológicos brasileiros.

Il selvaggio è móbile. O tema da inconstância ameríndia fez fortuna, dentro e fora da relfexão missionária, e 
EDSON K. DORNELES - O Rio: lugar sagrado da literatura ameríndia

bem além de seu exemplo primordial, os Tupinambá litorâneos. Serafim Leite, o historiador da Companhia de Jesus no Brasil, fundou-se na observação dos primeiros catequistas para identificar a "deficiência da vontade" e a "superficialidade dos sentimentos" como principais impedimentos da conversão dos índios. Mas socorreu-se também da opinião de leigos ... unânimes em apontar a amorfa da alma selvagem (...). Essa proverbial inconstância não foi registrada somente para as coisas da fé. Ela passou, na verdade, a ser um traço definidor do caráter ameríndio...(VIVEIROS DE CASTRO, 2011, p. 185-186).

A inconstância também é definidora da personalidade do rio. A troca silenciosa que ele desfere com a margem, com o céu, com seu leito e com seus habitantes pode também ser definida como uma predação ontológica (expressão de Viveiros de Castro), seu poder subversivo é intrínseco, e sua transgressão é imanente: do interior para o exterior. Diferente do lago, as imagens que o rio projeta são muitas, móveis, turvas.

Às vezes essas características tão afins à alma ameríndia são percebidas além-mar por outras sensibilidades estéticas.

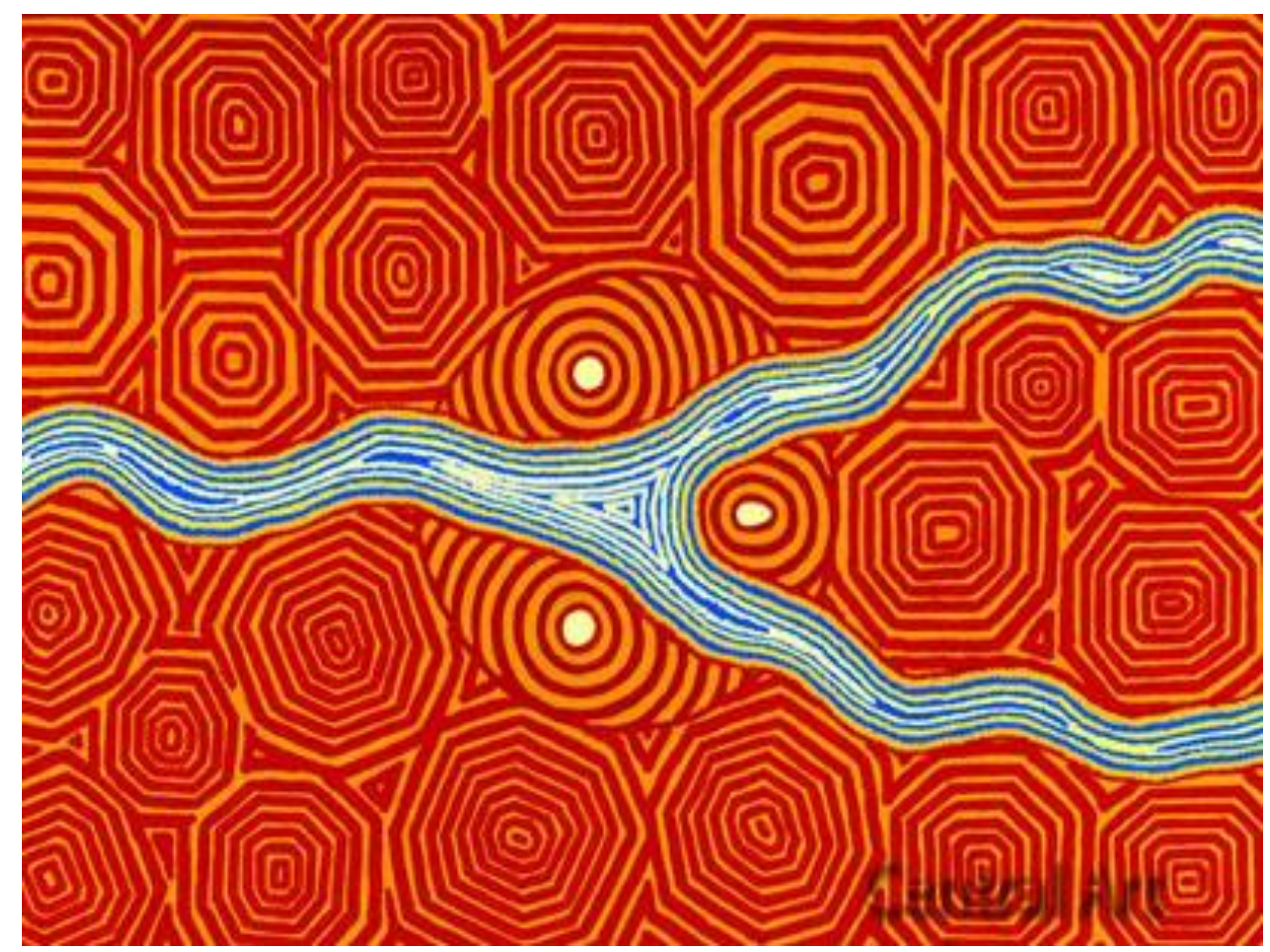

Figura 1: Water Dreaming, 1998 (JAGAMARA, 2012).

Espaço Ameríndio, Porto Alegre, v. 6, n. 2, p. 76-96, jul./dez. 2012. 
O artista aborígene australiano Malcolm Maloney Jagamara compreendeu o rio como um espaço que transmite afinidade e intocabilidade, uma imagem menos ambígua que ambivalente, como fica evidente em seu quadro Water Dreaming (figura acima), de 1998. As margens superiores e inferiores do quadro, compartilhando cores e tonalidades, não se tocam, nem internamente. Há uma tensão nas figuras geométricas que se diferem e se assemelham, losangos, triângulos e círculos se revezam como esferas de sentidos de domínios, mas que são rearranjados pelo rio no centro, no limiar, na fronteira do quadro e da terra representada. Todas as imagens possuiriam algo em comum - a cor, o tom, formas - mas estariam condenadas pela força transcendente do rio a permanecerem aí.

O poeta Perankô Panará expõe essa tensão ao retratar o amor e o rio neste poema:

\author{
Correr das pedras \\ Rio da vida, água clara \\ Correr das pedras \\ Peixes grandes, peixe pequeno \\ O sol nasceu \\ Na curva dos rios, água \\ de novo correu, \\ dentro do rio \\ Água linda, friazinha, \\ fica entrando no meu corpo \\ amando, beijando e bebendo \\ devagar \\ Sempre mata coração \\ No meu entrando \\ No peito sozinha deixando \\ Embora amor chore \\ Correr. (XACRIABÁ et al, 2007, p. 47).
}

O poema de forma sinuosa, como se fossem pedras de vários tamanhos, diques, protuberâncias dentro e fora do fio: o correr do rio contrasta com o calor do sol, a temperatura da água, não opõe, faz conviver o grande e o pequeno, o prazer e a dor. O rio representa a totalidade da vida: o nascer, o viver e o chorar (a morte?). O eu lírico 
busca, no correr do rio, a beleza que deve tomar sua alma mesmo diante de algo que pode matar o coração.

Em Órfãos do Eldorado, a personagem que abre a narrativa parece estar diante dessa mesma contingência da existência diante das águas: "a voz da mulher atraiu tanta gente, que fugi da casa do meu professor e fui para a beira do Amazonas. Uma índia, uma das tapuias da cidade, falava e apontava o rio" (HATOUM, 2008, p. 6).

As vozes no romance de Hatoum, plurais como todo o romance, assumem um tom diferente do conto de Guimarães Rosa, mas se aproximam quando se misturam os atores: a inconstância dos maridos, dos amantes, dos objetos de desejo de ambas as obras se aproximam do quadro de Jagamara: uma convivência entre o diferente e o igual. Um exemplo do conto de Rosa pode mostrar isso:

Nosso pai era homem cumpridor, ordeiro, positivo; e sido assim desde mocinho e menino, pelo que testemunharam as diversas sensatas pessoas, quando indaguei a informação. Do que eu mesmo me alembro, ele não figurava mais estúrdio nem mais triste do que os outros, conhecidos nossos. Só quieto. Nossa mãe era quem regia, e que ralhava no diário com a gente minha irmã, meu irmão e eu. Mas se deu que, certo dia, nosso pai mandou fazer para si uma canoa (ROSA, 2006, p. 2).

Mas eu sabia que ele agora virara cabeludo, barbudo, de unhas grandes, mal e magro, ficado preto de sol e dos pêlos, com o aspecto de bicho, conforme quase nu, mesmo dispondo das peças de roupas que a gente de tempos em tempos fornecia (ROSA, 2006, p. 13).

Nos dois trechos acima, em que o narrador trata do seu pai, percebemos uma mudança radical na aparência da personagem, imagem que ficara "escondida", "cozinhando" dentro de si, mas, como um rio que toma outro curso, que entorna em outra curva buscando seu próprio ritmo - o ritmo da inconstância permanente -, nossa personagem se transforma.

Inconstância da narrativa de Rosa aventa numa direção de instabilidade ontológica perene, como pergunta Luiz Tatit: "Como tornar habitual um acontecimento extraordinário?" (TATIT, 2010, p. 107). Constatação advinda do próprio narrador que diz jamais ter conseguido

Espaço Ameríndio, Porto Alegre, v. 6, n. 2, p. 76-96, jul./dez. 2012. 
EDSON K. DORNELES - O Rio: lugar sagrado da literatura ameríndia

se acostumar com a situação do pai. O pai estando perto e longe, indo e não indo, presente e ausente do seio familiar instaura uma percepção desesperada de inacabamento, do incompleto, do indeciso, uma tensão existencial perene.

A mesma incerteza podemos encontrar em Órfãos do Eldorado, na complexa relação de Arminto e Dinaura. Após alguns momentos de amor, sexo e palavras sussurradas, Dinaura desaparece. Arminto passa meses, anos sem vê-la e sem desistir dela. O rio instaura o lugar de possibilidade permanente de encontrá-la.

No poema dos Professores Indígenas do Acre (XACRIABÁ et al, 2007, p. 47) o açude é o lugar inconstância de um rio que, ora vem do alto ou de baixo, exige da vida uma observação, um descompasso e, sob um sol que mata o coração, a predação ontológica do viver humano.

Nesses textos o rio transforma a percepção de cada ator. Entre a vida na terra e no rio, é neste lugar que a vida se abre, a poesia se materializa, o desejo se renova. Como se uma nova dimensão se abrisse para o sujeito: a dimensão da poesia, do infinito, da eternidade, do sonho sempre possível, da nova terra e novos céus.

Também o rio se apresenta nessas narrativas como um espaço que provoca no homem uma necessidade de decifração, descoberta, conhecimento, tradução: para onde vai? Por que meu pai quer ali? Onde está Dinaura? Onde é o Eldorado? É no rio que essas vozes buscarão as respostas, ou mais perguntas...

\section{Um colecionador, um hospitaleiro de segredos}

Enróscate en mis labios y deja que te beba, para sentirte mío por un breve momento, $y$ esconderte del mundo $y$ en ti mismo esconderte, y oír voces de asombro en la boca del viento. Julia de Burgos (1998, p. 85).

Atitudes desnorteadas soam sem lógica para a maioria das pessoas. Quando a repetição se instala, o fantasma da loucura parece materializar-se, e, após uma coleção de perguntas sem respostas, um diagnóstico se estabelece.

Espaço Ameríndio, Porto Alegre, v. 6, n. 2, p. 76-96, jul./dez. 2012. 
EDSON K. DORNELES - O Rio: lugar sagrado da literatura ameríndia

"É necessária uma alma muito perturbada para realmente se deixar enganar pelas miragens do rio" (BACHELARD, 1997, p. 21). Isto porque, diferente das pedras e da terra, dos raios do sol e da solidez dos seres e plantas que habitam o espaço seco da natureza visível, as águas estão ligadas à imaginação, como se fosse um jogo de escondeesconde. Os segredos que levam o pai a permanecer no espaço do rio, que escondem os objetos que ora visitam, ora moram no rio - pedras, cidades, peixes, entre outros - e que escondem Eldorado dos exploradores, ou seja, Dinaura de Arminto, vão vitimizando seus corajosos interlocutores.

A coleção de segredos que o rio carrega é capaz de nos levar à foz, à morte ou à alegria da descoberta de um tesouro. O que estava na superfície parece tornar-se opaco para cada um de nossos personagens, e a travessia à profundidade das águas parece ser o caminho. A Barca de Caronte, que, na literatura, e, pela razão, leva sempre seus navegantes à morte, antes experimenta cada um nas torrentes fantasmagóricas, aterrorizadoras que talvez somente Marlow, personagem de Coração das trevas, de Joseph Conrad (CONRAD, 201 1), poderia descrever.

Quando tudo se torna água, foz, oceano, quando o filho resolve substituir o pai na missão e Arminto vai deixando de ser o filho do empresário para se parecer com os indígenas que ouve cantar à beira do rio, podemos afirmar que o segredo tem o poder de transformar. Uma das valências simbólicas da água, como vimos, é adentrar a sabedoria, é conhecer o segredo, o real.

O canto à beira do rio, como que para despertá-lo de seu sono, é um canto de tristeza, um clamor. O canto, invocação e expressão da alma, é a voz perene do rio no interior da floresta.

\section{Um cantor, aquele que murmura na floresta}

iRío Grande de Loíza!... Río grande. Llanto grande. El más grande de todos nuestros llantos isleños, si no fuera más grande el que de mí se sale por los ojos del alma para mi esclavo pueblo. Julia de Burgos (1998, p. 85). 
O desejo de mitigar o sofrimento do pai não é compartilhado por Arminto, mas a necessidade do "coração bater o compasso certo" (ROSA, 2006 , p. 80), tal como o filho do canoeiro, e também de rechaçar uma dor está presente. A observação do pai, seus gestos, sua preparação funcionam como um ritual que o coloca acima dos mortais, dos racionais. Arminto também é chamado de louco em muitos momentos.

O canto também é associado a um saber. Airton Krenak afirma que é uma das formas de se buscar o conhecimento ancestral e das práticas do povo (XACRIABÁ et al, 2007, p. 16). Mas o conhecimento desse real não é o que nos liga a ele, sim o sentimento apaixonante do real. Segundo Bachelard, é o sentimento de amarmos a natureza que nos leva a conhecê-la, a buscar seus detalhes, a mergulhar em seu rio. $E$ um sentimento filial, e assim como a natureza é uma mãe para o homem, as águas são o símbolo matricial supremo. E o canto do rio, do mar é o que atrai todos os homens, em todas as épocas, para ele (BACHELARD, 1997, p.120).

O rio é, no romance de Hatoum (2008), o centro, o eixo das tensões: ele rodeia a ilha de Eldorado, navega o cargueiro, atrai o mito, provoca o canto. Não menos central em Guimarães Rosa e igualmente onipresente na obra Te Mandei um Passarinho (XACRIABÁ et al, 2007).

O canto tem uma importância fundamental em várias etnias ameríndias: Quéchua, Terena, Umotina, Guarani, Kayapó, Krenak, entre outros $^{6}$. Para alguns o canto é um contrato, o início de um ritual. Dentro do coração da floresta, o som do rio pode ser o mesmo medo e tremor que alguns guerreiros sentem quando ouvem o canto dos deuses: no silêncio da mata, quando se ouve o rio, é porque outros animais já se foram. Mas também é esperança e certeza de que o sinal do pajé poderá ser percebido, peixe pescado, o caminho desejado encontrado. O rio é uma referência da memória e uma seta para o futuro, e seu canto o despertamento.

\footnotetext{
${ }^{6}$ Alguns sites até disponibilizam CDs produzidos por empresas nacionais e internacionais, exemplo do povo Kayapó neste website: http://pib.socioambiental.org/pt/povo/kayapo/193. Outros estudos aprofundam esta questão: http://www.povosdamazonia.am.gov.br, Cunha e Almeida (2002) e Clastres (1990).
}

Espaço Ameríndio, Porto Alegre, v. 6, n. 2, p. 76-96, jul./dez. 2012. 
O rio é o elemento xamânico imbloqueável, irresistível, por isso pode ser comparado ao canto xamânico, o qual veicula voz dos deuses ${ }^{7}$. Quando o rio canta, veicula vozes, seres transcendentais falam através dele. Talvez seja de fato um diálogo da tapuia com os deuses ou ancestrais no episódio de abertura de Órfãos do Eldorado. Os homens comuns podem até compreender como a voz da serenidade e da paz ("águas tranquilas" do Salmo 23 bíblico (BíBLIA, 2012)). Mas em nossa intuição, essa voz nos leva a outra dimensão, do sagrado, da prerrogativa espiritual enquanto criadora de sentidos.

As vozes, os sons não podem ser capturados, impedidos e bloqueados. Muitas vezes, essas águas aqui observadas escaparão, como o grande rio de Conrad em Coração das Trevas, à expressão articulada. Mas de poder simbólico estrondoso: "O riacho, o rio, a cascata têm pois um falar que os homens compreendem naturalmente. Como diz Wordsworth, 'uma música de humanidade': The still, sad music of humanity. Lyrical Ballads" (BACHELARD, 1997, p. 205). Mas do murmúrio do interior de uma concha um rumor das ondas, a voz de muitas águas (expressão bíblica) o estrondo de uma cascata ou de uma tromba pode vir inesperadamente.

\section{Um monstro capaz de destruir tudo quando está com raiva}

Muy señor río mío. Río hombre. Unico hombre que ha besado mi alma al besar en mi cuerpo. Julia de Burgos (1998, p. 85).

A ideia da violência associada às águas está bem presente no mundo atual, desde que os tsunamis entraram para as matérias jornalísticas e histórias de lugares. Mas bem antes, a ideia de um dilúvio primordial parece estar presente não somente nas populações litorâneas, mas ribeirinhas também.

A violência, mesmo metaforizada, é talvez o canto mais forte das águas, não a morte. Por isso, seguindo a perspicácia do estudo de Bachelard (1997), que afirma que, na vã empreitada de conter a cólera

\footnotetext{
${ }^{7}$ Embora dispondo de muitas informações corretas e de bibliografia séria, este website - de onde retiramos essa informação - levanta suspeitas por tentar homogeneizar e banalizar os rituais nativos de terras tão diferentes como a região do Xingu e da Austrália. http://www.xamanismo.com.br.
}

Espaço Ameríndio, Porto Alegre, v. 6, n. 2, p. 76-96, jul./dez. 2012. 
de um rio, o homem tentar inverter a violenta água em água violentada. Girard (1997) mostrou a valência feminina dos símbolos ligados à água matricial, e em sua reação violenta essa valência assume uma simbologia ponerológica, materialização do maléfico, em oposição à valência matricial, masculino.

"O procedimento desatinado" do filho do canoeiro, a tentativa de fazer o mesmo que ele dos Karajá após o abandono do rio, encontra um alento fraco e ressentido em Arminto; representante dos que trazem a modernidade para a cidade, as doenças, a fome, a ambição não consegue conviver com a fortuna da família, mas ao mesmo tempo leva sua tradutora e companheira Florita à miséria. $O$ rio na vida desses personagens também foi desatino, violência sofrida e agenciada.

A tromba d'água, resultado de acúmulo de água na nascente ou nas cabeceiras do rio, traduz uma realidade que dificilmente se espera à margem de um rio. Mas a violência que se depara no rio não vem somente da inesperada tromba d'água, vem da luta contra um corpo inabraçável, que se agita sem parar e que é preciso vencê-lo a cada braçada.

Enquanto o canoeiro espera tácito o rio transformá-lo, mas sem luta, as tapuias também se entregam às águas, sem luta, na narrativa hatouniana.

Violência, luta, sofrimento são palavras que carregam e aceleram a difusão de sentidos que a realidade indígena - esse povo das águas nos remete. Todas as narrativas que citamos experimentam o silêncio catatônico da violência numa gradiência de exemplos que podem ir de ondas (in)constantes a profetizadas trombas d'água. A história das populações autóctones experimentou uma tromba d'água chamada colonialismo no século XIX, que só poderia ser repetida por ondas espaçadas durante os séculos posteriores.

A violência contra o rio aponta para um tipo específico de violência humana, o etnocídio. Pierre Clastres o define como a destruição, não somente dos homens de uma raça ou minoria, mas de sua cultura: "é a destruição sistemática dos modos de vida e pensamento de povos diferentes daqueles que empreendem essa destruição" (CLASTRES, 2012, p. 78). A origem do termo etnocídio é diretamente associada à situação dos povos indígenas da América do 
sul. O filósofo francês afirma que o "genocídio assassina os homens em seu corpo, o etnocídio em seu espírito" (CLASTRES, 2012, p. 79).

O rio representa essa vida espiritual dos homens: jorra, corre e deságua; mas sofre com a interferência de elementos internos, pois é de sua natureza seguir seu curso, entre margens, recebendo e doando vida. O rio convive com seu diferente, com a margem, a terra, a porção seca, dando-Ihe o que precisa, fecundando-a permanentemente. Ele não a destrói. É sabido que o rio devolve o que é jogado nele. Mas o homem tem destruído o que entra em sua cultura.

No caso dos indígenas, Levi-Strauss lembra como estes viam os espanhóis recém-chegados: deuses ou homens? Enquanto os espanhóis questionavam se eram animais ou se tinham alma (apud CLASTRES, 2012, p. 31). É clara a diferença fundamental entre os povos do rio e da terra. O rio jamais viu na margem a destruição de seu mundo; mas a chegada de um novo mundo para os indígenas implicou a destruição do seu.

A hierarquia que fundamenta a prática etnocida, quem é superior/inferior, não opera no espírito do rio: ele busca os lugares mais baixos, se abaixa para conviver em sua própria força e leito. A dificuldade de tradução presente nas narrativas parece testemunhar uma dificuldade de conviver com o pensamento etnocêntrico: como definir/avaliar/descrever o Outro?

O jogo perspectivista de vozes, de pluralidades, a gradiência tensiva dos actantes dessas narrativas mostram que é possível pensar, definir e até julgar o outro, mas sem destruí-lo.

Clastres, procurando descobrir as causas do etnocídio da sociedade ocidental, afirma que o "etnocídio resulta da dissolução do múltiplo no UM" (CLASTRES, 2012, p. 83), ou seja, uma sociedade que coloca os interesses múltiplos dos cidadãos nas mãos de um Estado, que opera como uma força centrípeta que procura "esmagar as forças centrífugas diversas" (CLASTRES, 2012, p. 83). Isso fica patente ao percebermos como as crianças indígenas são homogeneizadas em sua língua, discurso, educação e relações sociais dentro do romance de Hatoum (2008), ao serem levadas de suas aldeias para o orfanato:

Florita me disse que várias órfãs falavam a língua geral; estudavam o português e eram proibidas de

Espaço Ameríndio, Porto Alegre, v. 6, n. 2, p. 76-96, jul./dez. 2012. 
EDSON K. DORNELES - O Rio: lugar sagrado da literatura ameríndia

conversar em língua indígena. Vinham de aldeias e povoados dos rios Andirá e Mamuru, do paraná do Ramos, e de outros lugares do Médio Amazonas (HATOUM, 2008, p. 36).

A negação da diferença opera aí como um contrato entre a sociedade urbana e o Estado.

A outra causa, na esteira do pensamento de Clastres, que torna a sociedade ocidental etnocida é seu regime de sistema econômico. Mais uma vez uma forma de vida oposta ao do rio. O sistema econômico intensificado pela era do consumismo - é o espaço do ilimitado, da impossibilidade de recuo, do limite. O rio, por outro lado, é o espaço da vida ecológica, do equilíbrio, conhece seus limites, convive com eles, recua, desaparece, deságua e somente à mercê do juízo divino sobre os homens é que cobrem a Terra.

O "povo da terra", construtor de cidades e estradas, condenou à morte as comunidades indígenas que encontraram pelo caminho ao longo dos últimos 200 anos. Exemplar é o caso dos Waimiri Artoari, que desapareceram depois de sua resistência à construção da rodovia BR174 durante a ditadura brasileira.

A cidade e o rio ventilam, dentro dessa perspectiva, ethos não somente opostos, mas que dentro de cada semiosfera (esfera semiótica) sentidos são trocados, num espaço tensivo onde centro e periferia são, no mínimo, móveis. O rio proporciona uma "matéria uniforme a ritmos diferentes" (BACHELARD, 1997, p. 193), enquanto a cidade estabelece a dureza poética, a incapacidade de reagir, se adaptar fluir. $O$ poder que se o opõe ao rio o contamina por dentro, sujando-o, eliminando sua capacidade de gerar vida. A cidade erige-se como o espaço da violência, onde a natureza, a comunidade e a espiritualidade são suprimidas ou neutralizadas para dar lugar à modernidade.

Foz

¿A dónde te llevaste las aguas que bañaron mis formas, en espiga de sol recién abierto? Julia de Burgos (1998, p. 85).

Espaço Ameríndio, Porto Alegre, v. 6, n. 2, p. 76-96, jul./dez. 2012. 
EDSON K. DORNELES - O Rio: lugar sagrado da literatura ameríndia

Amazônica, esta foz difere de uma foz afunilada ou como de um delta egípcio. Ela deve se abrir num conglomerado de ilhas, rios e canais, portanto, mista, heterogênea, não conclusiva, prenha e já parturiente de outras ramificações, corredeiras.

Essas narrativas fluviais onde destacamos a valência do rio e sua actância espaço-temporal, como também a simbólica matricial da água, nos fez ver movências e configuração de imagens identitárias. Como espaço de tradução de vozes, origens e destinos fluidos e híbridos, às vezes transitórios, porque sempre abertos ao amplo ou ao exíguo.

Não concordamos que a ponte, um elemento externo ao rio e à natureza, possa fazer traduzir as vozes diferentes que protagonizam a história do homem, como nesta afirmação de Barbara Johnson:

A ponte da tradução, que paradoxalmente liberta
dentro de cada texto as forças, subversivas de sua
própria estrangeiridade, reinscreve, dessa forma, essas
forças na resistência da tensão de uma nova vizinhança
de alteridade. Apesar disso, todos os viajantes nessa
ponte estão respondendo a um apelo que os repele a
cada passo, um apelo que lembra a placa colocada por
Lautréamont, na frente de Maldoror, contendo um aviso
que se recebe tarde demais para que se possa atendê-
lo: vous, qui passez sur ce pont, n'y allez pas, "Vós,
que estais atravessando esta ponte, não chegueis ao
outro lado" (JOHNSON, 2005, p. 34).

Pelo contrário, é o rio metáfora e símbolo maior da tradução, pois é ele quem recebe de todos os lados a riqueza da estrangeiridade. As forças de obstinação e generosidade pertencem a ele. Os viajantes do rio são os que vivem a tensão da tradução: ao mesmo tempo em que ele permite o vislumbre do outro lado, ele resiste a essa chegada, tenta impedir. Essa resistência se liga ao que Derrida chama de tradutibilidade fundamental, que se liga poeticamente a uma língua natural e resiste à tradução. A ponte de pedra ou de outro material duro implica uma completude não inerente ao rio. Se há determinação, diferenciação, separação, necessidade de traduzir-se, pertence às margens, à cidade. É o rio que torna possível, a todo momento, a possibilidade de uma manifestação do homem (DERRIDA, 2005, p. 170-174). Claro, a ponte nos leva ao outro lado sem termos que enfrentar esse bebê que às vezes é um monstro, o rio, por isso a amamos, como o narrador de Los Ríos

Espaço Ameríndio, Porto Alegre, v. 6, n. 2, p. 76-96, jul./dez. 2012. 
Profundos, de José María Arguedas: "Yo no sabía si amaba más al puente o al río. Pero ambos despejaban mi alma, la inundación de fortaleza y de heroicos sueños. Se borraban de mi mente todas las imágenes plañideras, las dudas, los malos recuerdos" (ARGUEDAS, 2010, p. 59).

A inconstância do rio é a inconstância da alma ameríndia que se pauta numa revisão constante do Outro: canibalismo permanente, afinidade e inimizade são valências desse canibalismo ameríndio (VIVEIROS DE CASTRO, 2011). O rio requer essa tomada de posição em relação ao outro, não para destruí-lo ou ignorá-lo, como uma ponte que passa sobre o rio sem tocá-lo. A impossibilidade de pontes nas comunidades ameríndias está subentendida numa aceitação do rio.

O rio é a geografia - a medida, o mapa - do mundo. Essa constância em medir e delimitar o mundo não esconde sua inconstância, seu ritmo, sua voz. Em qualquer lugar sua voz e ritmo são o convite ao Outro: oferece comida ou devora. Sua relação com os homens e com os animais é a mesma, ele não os difere, ou melhor, os diferindo, trata como iguais. Por isso pensar a literatura ameríndia é pensar a abertura ao Outro...

A história do rio é a história de contatos, encontros e desencontros. Simbolizá-lo é insuficiente, deve-se buscar as valências de sua semiótica. Pois ele é, aqui, a pedra onde amolamos nossa análise.

Inundação de ausência, presença, limites e superficialidade, profundidade e eternidade, vivacidade e clareza, escuridão e morte são valências que o rio coleciona para narrar a vida dos homens; e como esta, não partilha de uma origem - está sempre jorrando, de/para algum lugar.

Muitas vezes esse relato é um acúmulo de destroços, de violência e dor, mas também multiplica - porque seu sentido é multiplicar - a vida, as espécies, as formas.

\section{Referências bibliográficas}

ARGUEDAS, J. María. Los Rios Profundos. Lima: Escolar, 2010. 
EDSON K. DORNELES - O Rio: lugar sagrado da literatura ameríndia

BACHELARD, Gaston. A água e os sonhos. São Paulo: Martins Fontes, 1997.

BIBLIA. Versão corrigida. 2012. Disponível em: www.bibliaonline.com.br . Acesso em: 13 jun. 2012.

BLOOM, Valerie. River. 2012. Disponível em: www.poetryarchive.com . Acesso em: 20 mar. 2012.

BORGES, Jorge L. Poemas de Jorge Luis Borges. 2012. Disponível em: http://www.los-poetas.com/b/borges1.htm . Acesso em: 20 mar. 2012.

BURGOS, Julia de. Song of the Simple Truth: The Complete Poems of Julia de Burgos, Obra Completa Poetica. Publishers Weekly, 24 fev. 1998, p. 85.

CLASTRES, Pierre. A fala sagrada: mitos e cantos sagrados dos índios guaranis. Campinas: Papirus, 1990.

Arqueologia da violência. São Paulo: Cosac Naify, 2012.

CLAVAL, Paul. A terra dos homens, a geografia. São Paulo: Contexto, 2010.

CONRAD, Joseph. O coração das trevas. Porto Alegre: LPM, 2011.

CUNHA, Manuela Carneiro da; ALMEIDA, Mauro Barbosa de (Orgs.). Enciclopédia da floresta: o Alto Juruá - práticas e conhecimentos das populações. São Paulo: Companhia das Letras, 2002.

DERRIDA, Jacques. Teologia da tradução. In: OTTONI, Paulo. (Org.). Tradução a prática da diferença. Campinas: Unicamp, 2005. p. 21.

ELIADE, Mircea. Imagens e Símbolos. São Paulo: Minerva, 1979.

GIRARD, Marc. Os símbolos da Bíblia. São Paulo: Paulus, 1997.

HATOUM, Milton. Órfãos do Eldorado. São Paulo: Cia. Das Letras, 2008.

IHIMAERA, Witi. The whale rider. Auckland: Heinnemann, 1987.

IMS, Instituto Moreira Salles. Revista Cadernos de Literatura Brasileira: Dossiê Guimarães Rosa, São Paulo, n. 20-21, dez. 2006.

JAGAMARA, Malcolm. Water Dreaming. 1998. Disponível em: http://www.aboriginalartstore.com.au/aboriginal-art-culture/water-dreaming-audiointerview.php. Acessado em 20/05/2012 . Acesso em: 23 dez. 2012.

JOHNSON, Barbara. A fidelidade considerada filosoficamente. In: OTTONI, Paulo. (Org.). Tradução a prática da diferença. Campinas: Unicamp, 2005. p. 29-36. 
NASCIMENTO FILHO, Antonio José. Bartolomeu de Las Casas: um cidadão universal. São Paulo: Loyola, 2005.

ROSA, João Guimarães. Primeiras Estórias. São Paulo: José Olímpio, 1969.

A terceira margem do rio. In: Primeiras estórias. Rio de Janeiro: Nova Fronteira, 2006. p.79-85.

TATIT, Luiz. Semiótica à luz de Guimaraes Rosa. São Paulo: Atelie Editorial, 2010.

VIVEIROS DE CASTRO, Eduardo. A inconstância da alma selvagem. São Paulo: Cosac Naify, 2011.

XACRIABÁ et al. Te Mandei um Passarinho: prosas e versos de índios do Brasil. Brasília: MEC, 2007.

ZILBERBERG, Claude. Elementos de Semiótica Tensiva. São Paulo: Ateliê Editorial, 2011.

Espaço Ameríndio, Porto Alegre, v. 6, n. 2, p. 76-96, jul./dez. 2012. 